\title{
Endometrial expression of mRNA encoding insulin-like growth factors I and II and IGF-binding proteins 1 and 2 in early pregnant ewes
}

\author{
C. H. Cann ${ }^{1,2}$, R. J. Fairclough ${ }^{2 *}$, R. Sutton ${ }^{3}$ and C. B. Gow ${ }^{1}$ \\ ${ }^{1}$ School of Agriculture, Faculty of Science and Technology, La Trobe University, Bundoora, 3083, Victoria, \\ Australia; ${ }^{2}$ Victorian Institute of Animal Science, Werribee, 3030, Victoria, Australia; and ${ }^{3}$ Division of \\ Animal Production, CSIRO, Blacktown, New South Wales, 2148, Australia
}

\begin{abstract}
The temporal variations in endometrial expression of mRNA encoding insulin-like growth factor I (IGF-I) and IGF-II, and insulin-like growth factor-binding protein I (IGFBP-I) and IGFBP-2 were investigated between oestrus and day 20 of pregnancy in ewes. Northern blot analysis of endometrial total RNA revealed major transcripts for IGF-I (7.1 kb), IGF-II $(5.8 \mathrm{~kb})$, IGFBP-1 (1.3 kb) and IGFBP-2 (1.7 kb). Some minor transcripts for IGF-II were also detected. The low endometrial expression of mRNA encoding IGF-I at day 15 of pregnancy was used as the reference point for time comparison for expression of mRNA encoding IGF-I, IGF-II and IGFBP-2. The mRNA encoding IGFBP-1 was not quantitated since the gene was expressed only on day 15 of pregnancy. Endometrial expression of mRNA encoding IGF-I was increased $(P<0.05)$ at oestrus and on day 8 of pregnancy relative to expression on day 15, whereas expression of mRNA encoding IGFBP-2 was decreased $(P<0.05)$. The major IGF-II transcript was unaffected by day of pregnancy. The temporal variation of the expression of mRNAs encoding IGF-I and IGFBP-2 suggests a role for these factors in the uterine environment during early pregnancy in ewes coinciding with rapid development of the embryo and growth of the uterus in preparation for implantation.
\end{abstract}

\section{Introduction}

Over the past decade uterine-derived factors that may induce embryo or uterine growth and development in vivo have been identified. A variety of growth factors, including epidermal growth factor, transforming growth factor $\alpha$, colony stimulating factor 1 , heparin-binding growth factors and members of the IGF family, have been isolated in uterine tissues and fluids from various species (see Brigstock et al., 1989). In particular, the IGFs have been implicated in cellular proliferation and differentiation of the preimplantation mammalian embryo. Concentrations of IGF-I are high in uterine flushings of sows on day 12 of pregnancy, coinciding with rapid embryo development (Letcher et al., 1989), and of ewes on days 10-16 of pregnancy (Ko et al., 1991). Both IGF-I and IGF-II are present in uterine flushings of cows at oestrus and during early pregnancy, particularly on day 5 (Geisert et al., 1991). In addition, temporal variation in mRNA encoding IGF-I occurs in the uterus of pregnant sows (Letcher et al., 1989; Simmen et al., 1992). mRNAs encoding both IGF-I and IGF-II are also present in the endometrium of pregnant cows (Geisert et al., 1991) and ewes (Stevenson et al., 1994). Furthermore, mRNA encoding IGF-I is temporally regulated in ewes, with increased expression at oestrus relative to that on days 2-15 of pregnancy (Stevenson et al., 1994). However, temporal variations have not been observed in the expression of mRNAs encoding IGF-I and

*Present address: Department of Food Technology, Victoria University of Technology, Werribee, 3030, Victoria, Australia.

Revised manuscript received 7 May 1997.
IGF-II in cows (Geisert et al., 1991) or in the expression of mRNA encoding IGF-II alone in ewes (Stevenson et al., 1994).

Receptors for the IGFs and mRNA encoding them have been localized on embryos of several species. In mouse embryos, the expression of mRNA encoding IGF-I receptors occurs before the expression of mRNA encoding IGF-I (Heyner et al., 1989a, b), suggesting a paracrine action of maternally derived IGF-I before implantation. In contrast, the coincidental expression of mRNA endoding IGF-II (Harvey and Kaye, 1991) and IGF-II receptor (Rappolee et al., 1989; Werb, 1990) at around the two-cell stage of development in mice suggests an autocrine action of this peptide. However, mRNA encoding IGF-I receptor has been detected in the uterus of rats (Ghahary and Murphy, 1989), while mRNAs encoding IGF-I and IGF-II receptors have also been detected in the endometrium of gilts (Simmen et al., 1992) and ewes (Stevenson et al., 1994), supporting the presence of an autocrine mechanism by which maternally derived IGF-I or IGF-II may directly affect the development of the uterus in preparation for implantation.

Locally derived IGFBPs may also play a role in the uterine environment. In the circulation at least $98 \%$ of both IGF-I and IGF-II is stored as a protein-binding protein complex (Baxter, 1991) which serves to extend the half-lifes of IGF-I and IGF-II (Cohen and Nissley, 1976) and provide a storage reservoir of the IGFs (Bar et al, 1990). Indeed, expression of the mRNAs encoding several IGFBPs has been identified in the uterine tissue of various species. The mRNA encoding IGFBP-1 is present in rat uterus (Murphy et al., 1990) and IGFBP-1 has been localized in human endometrium during early pregnancy 
(Hustin et al., 1994). In addition, mRNA encoding IGFBP-2 has been detected during early pregnancy in gilts (Simmen et al., 1992) and cows (Geisert et al., 1991), and appears to be regulated by steroids. Furthermore, Stevenson et al. (1994) suggest that IGFBP-I or IGFBP-2, or both, are produced locally in the deep stroma and glands of the ovine uterus. Together, these data imply that uterine IGFBPs may play a role in the regulation or modulation of IGF-I and IGF-II action in the uterine environment.

These studies suggest a role of uterine IGF-I and IGF-II during the preimplantation period in ewes. Although mRNAs encoding IGF-I and IGF-II have been localized in the endometrium of ewes during early pregnancy, at the time of this study specific windows of expression of either mRNA encoding IGF-I or mRNA encoding IGF-II in the uterus have not been identified. Furthermore, it is likely that IGFBP-1 and IGFBP-2 have a regulatory role in the uterine environment but the variations of the mRNAs for these proteins have not been investigated in the uterus of ewes during early pregnancy. The present study examined the expression of mRNAs encoding IGF-I, IGF-II, IGFBP-1 and IGFBP-2 in the endometrium of early pregnant ewes.

\section{Materials and Methods}

\section{Animals and experimental protocol}

Fifty, 3-4 year-old Merino ewes (bodymass approximately $50 \mathrm{~kg}$ ) were selected from a single flock during the breeding season and were grazed on improved dryland pasture. Oestrus was synchronized by the insertion of an intravaginal sponge impregnated with $60 \mathrm{mg}$ medroxyprogesterone acetate (Repromap Intravaginal Sponge for Sheep, Upjohn Pty. Ltd, Rydalmere, NSW) for 12 days. Two days after removal of the sponges, ewes were observed for oestrous behaviour with the aid of rams fitted with harnesses and crayons (Sire-Sine, Cheetham Rural, Brisbane, Queensland). The ewes were checked for crayon markings at least every $24 \mathrm{~h}$ and the day of mating was designated day 0 of pregnancy.

The ewes were selected randomly for hysterectomy on days $0,3,6,8,15$ or 20 after oestrus. After overnight fasting, general anaesthesia was induced in each ewe by an intravenous injection of a mixture of pentobarbitone sodium (180 mg; Nembutal, Boehringer Ingelheim, Artarmon, NSW) and thiopentone sodium (350-600 mg; Intraval sodium, Rhone Merieux Animal Health, West Footscray, Victoria) followed by gaseous anaesthesia with a halothane oxygen mixture (Fluothane, ICI, Melbourne, Victoria). The uterus was exteriorized and flushed with isotonic $(0.9 \%, w / v)$ saline. The uterine flushing was examined for the presence of an embryo to confirm pregnancy in each ewe and embryos were examined for appropriate stage of development and quality. If pregnancy, embryo quality and the appropriate stage of embryo development were confirmed, the ewe was hysterectomized, and the endometrial tissue was dissected from the uterine horn ipsilateral to the corpus luteum within 20 min of collection of the uterine flushing. The endometrial tissue was washed free of blood with cold PBS $\left(0.01\right.$ mol $\mathrm{NaPO}_{4} \mathrm{l}^{-1}, \mathrm{pH} 7.4$, containing $0.15 \mathrm{~mol} \mathrm{NaCl} \mathrm{l}^{-\mathrm{I}}$ ), snap-frozen in liquid nitrogen and stored at $-70^{\circ} \mathrm{C}$ before extraction of total RNA. This procedure was repeated until pregnancy was confirmed in five ewes per time period, except on day 20 when four ewes were hysterectomized.

All experimental work was carried out with the prior approval of the Animal Experimentation Ethics Committee at the Victorian Institute of Animal Science, Werribee, and in compliance with the Australian Code of Practice for the Care and Use of Animals for Scientific Purposes.

\section{cDNA probes}

The IGF-I and IGF-II CDNA probes were PCR-amplified DNA fragments that represented part of the protein coding region of ovine IGF-I (289 bp) and ovine IGF-II (310 bp). The PCR amplification was carried out with cDNA made from RNA isolated from fetal sheep skin (Sutton et al., 1995). The cDNAs encoding IGFBP-I and IGFBP-2 were kindly provided by $V$. Han (University of Western Ontario, Lawson Research Institute, London, Ontario) and were cloned from an ovine liver cDNA library. The IGFBP-1 cDNA was the 500 bp Eco RI fragment encoding the carboxyl portion of the sheep IGFBP-1 (Phillips et al., 1991) and the IGFBP-2 cDNA was the $784 \mathrm{bp}$ Sma I-Sac I fragment encoding the midregion of the sheep IGFBP-2 (Delhanty and Han, 1992).

\section{Northern blot analysis}

Northern blot analysis was used to screen the endometrial samples for mRNAs encoding IGF-I, IGF-II, IGFBP-I and IGFBP-2. Total RNA prepared from endometrium collected from ewes in oestrus was used as a positive control for IGF-I and IGF-II on all northern blots (Stevenson et al., 1994). Similarly, a sample of total RNA prepared from liver collected from mature ewes was included as a positive control for IGFBP-1 and IGFBP-2 as these genes have been shown to be strongly expressed in this tissue in our laboratory.

Total RNA was isolated using a guanidium thiocyanate extraction and then centrifugation on a caesium chloride cushion as described by Chirgwin et al. (1979). Samples of total RNA (15 $\mu \mathrm{g})$ were denatured and electrophoresis was performed in $1 \%$ agarose/formaldehyde gels before transfer to a nylon membrane (Hybond-N; Amersham, North Ryde) by capillary blotting. The RNA was UV-fixed onto the filters using an automated cross-linker (UV Stratalinker 1800, Stratagene, La Jolla, CA).

Filters were hybridized sequentially with cDNA probes for IGF-I, IGF-II, IGFBP-I and IGFBP-2, and with a rat CDNA probe for glyceraldehyde phosphate dehydrogenase (GAPDH) to enable normalization of blots for RNA loading differences. All probes were labelled with $\left[{ }^{32} \mathrm{P}\right]$ deoxy-CTP (specific activity $3000 \mathrm{Ci} \mathrm{mmol}^{-1}$; Du Pont, North Ryde) by random oligonucleotide-primed synthesis (Random Primed Labelling Kit; Boehringer Mannheim, Castle Hill, NSW) and were used at a specific activity of $10^{6}$ counts $\mathrm{min}^{-1} \mathrm{ml}^{-1}$ of hybridization solution. Filters were prehybridized in Rapid Hybridisation Buffer (Amersham) at $65^{\circ} \mathrm{C}$ for $30 \mathrm{~min}$ and then hybridized for $3 \mathrm{~h}$ at $65^{\circ} \mathrm{C}$ in the same buffer with the addition of the appropriate probe. Filters were washed to a stringency of 
$0.1 \times \mathrm{SSC}$ (single strength $\mathrm{SSC}=0.15 \mathrm{~mol} \quad \mathrm{NaCl} \mathrm{I}^{-1}$, 0.015 mol sodium citrate $\left.1^{-1}\right)$ containing $0.1 \%(w / v)$ SDS at $65^{\circ} \mathrm{C}$. The hybridization signals were detected by exposing filters to X-ray film (Fuji Photo Film Co. Ltd, Tokyo) with intensifying screens (Du Pont Cronex, Boston, MA) at $-70^{\circ} \mathrm{C}$ for $2-7$ days. The filters were stripped in boiling $0.5 \%$ $(w / v)$ SDS in between hybridizations and were checked for residual message using autoradiography to allow consecutive hybridization with each probe.

Signals for mRNAs were quantitated using scanning densitometry (Imagequant ${ }^{(i x}$ software linked to a computing densitometer; Molecular Dynamics, Sunnyvale, CA). Signals were expressed as an arbitrary unit above background for each autoradiograph and were adjusted for RNA sample loading differences by expressing each message as a ratio of the GAPDH message. The lowest endometrial expression of mRNA encoding IGF-I was used as the reference point for time comparison for expression of mRNAs encoding IGF-I, IGF-II, IGFBP-I and IGFBP-2. Northern blot analysis of all genes was performed on duplicate filters.

\section{Statistical analysis}

Expression data were analysed using a Fisher's LSD test (Minitab, Minitab Inc., State College, PA) to evaluate the effect of day of pregnancy on expression of mRNA encoding IGF-I, IGF-II and IGFBP-2 in the endometrium.

\section{Results}

Northern blot hybridization identified a major mRNA transcript encoding IGF-I $(7.1 \mathrm{~kb})$, IGF-II $(5.8 \mathrm{~kb})$ and IGFBP-2 (1.7 kb) throughout pregnancy in the endometrium of pregnant ewes (Fig. 1). Overexposure of the autoradiograph also allowed detection of a number of minor mRNA transcripts encoding IGF-II (4.4, 3.3-3.7, 2.6-2.7, 2.0, and $\sim 1.2 \mathrm{~kb}$; Fig. 2). A major transcript encoding IGFBP-1 ( $1.3 \mathrm{~kb})$ was detected in the endometrium of the ewes on day 15 of pregnancy only (Fig. 3).

The relative expression of mRNA encoding major transcripts for IGF-I, IGF-II and IGFBP-2 were quantified after adjusting for differences in RNA loading by analysis of GAPDH expression and, therefore, represent true differences in signal intensity. The lowest endometrial expression of mRNA encoding IGF-I was used as the reference point and occurred on day 15 of pregnancy. The data were clarified for comparison purposes by giving the arbitrary measures of expression of mRNA transcripts encoding all genes relative to the mean expression on day 15. This time also coincides with maternal recognition of pregnancy and the beginning of adherence of the embryo to the uterine wall in ewes and, therefore, represents a relevant comparison point.

Densitometric analyses indicated that the expression of the mRNA encoding IGF-I, relative to the mean value recorded on day 15 , was affected $(P<0.05)$ by day of pregnancy (Fig. $4 a$ ). The endometrial expression of mRNA encoding IGF-I was higher $(P<0.05)$ at oestrus (day 0$)$ and on days 6 and 8 of pregnancy compared with expression on day 15 of pregnancy. In contrast, the endometrial expression of the major mRNA

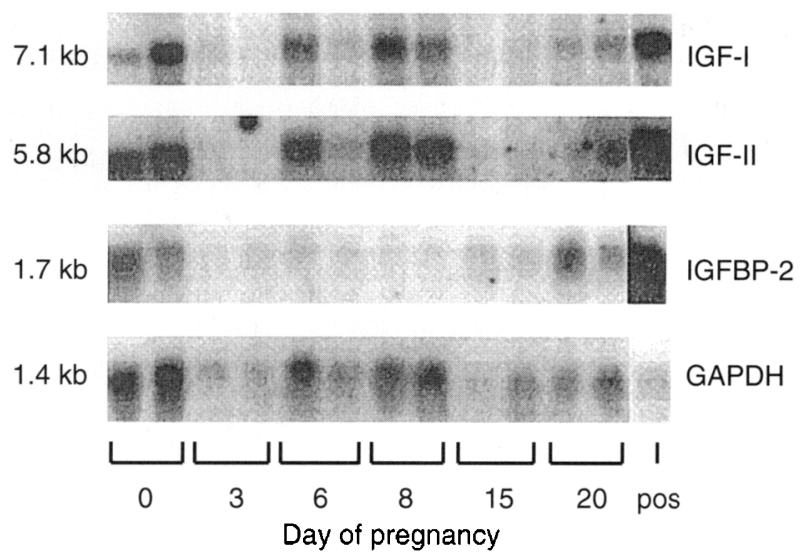

Fig. 1. Representative northern blot analyses showing hybridization of ${ }^{32}$ P-labelled probes to major mRNA transcripts encoding insulinlike growth factor I (IGF-I), IGF-II, insulin-like growth factor binding protein 2 (IGFBP-2) and glyceraldehyde phosphate dehydrogenase (GAPDH). Results of hybridization to total RNA (15 $\mu \mathrm{g})$ extracted from endometrium collected from two ewes at oestrus (day 0) and from day 3 to day 20 of pregnancy are shown, together with positive control samples for IGF-I, IGF-II and IGFBP-2 (pos). Autoradiographs were produced after sequential hybridizations and were exposed for 2 days, 4 days 5 days and 1 day for mRNA encoding IGF-I, IGF-II, IGFBP-2 and GAPDH, respectively.

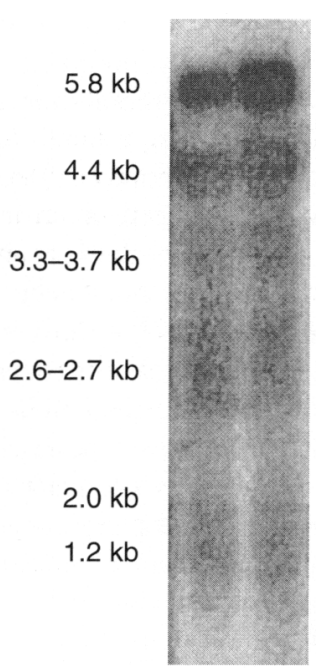

Fig. 2. Representative northern blot analysis showing hybridization of a ${ }^{32}$ P-labelled probe to a major mRNA transcript encoding insulin-like growth factor II. Results of hybridization to total RNA ( $15 \mu \mathrm{g}$ ) extracted from endometrium collected from two ewes at oestrus (day 0) are shown. The autoradiograph was exposed for 4 days.

transcript encoding IGF-II, relative to that on day 15, was not affected by day of pregnancy (Fig. $4 \mathrm{~b}$ ). The relative expression of mRNA encoding IGFBP-1 was not quantified since message was detected only on day 15 of pregnancy and no real comparisons could be made. However, the expression of mRNA encoding IGFBP-2, relative to the mean value recorded on day 15 , was quantified and was affected $(P<0.05)$ by day of pregnancy (Fig. $4 \mathrm{c})$ with high $(P<0.05)$ values at oestrus and low $(P<0.05)$ values at day 8 . 


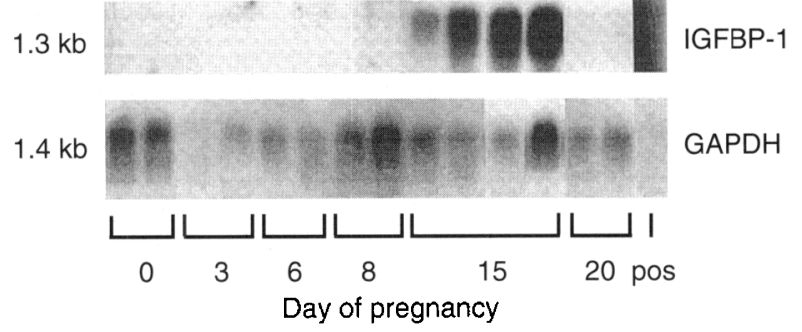

Fig. 3. Representative northern blot analysis showing hybridization of a ${ }^{32}$ P-labelled probe to a major mRNA transcript encoding insulin-like growth factor binding protein 1 (IGFBP-1) and glyceraldehyde phosphate dehydrogenase (GAPDH). Results of hybridization to total RNA $(15 \mu \mathrm{g})$ extracted from endometrium collected from two ewes at oestrus (day 0 ) and from day 3 to day 20 of pregnancy are shown, together with a positive control sample for IGFBP-I (pos). Autoradiographs were produced after sequential hybridizations and were exposed for 5 days and 1 day for mRNA encoding IGFBP-I and GAPDH, respectively.

\section{Discussion}

The present study used Northern blot analysis of gene expression and confirmed a previous report of the presence of mRNA for IGF-I and IGF-II in the endometrium of early pregnant ewes (Stevenson ef al., 1994). The illustration in the present study of endometrial expression of mRNA encoding IGFBP-1 and IGFBP-2 in early pregnant ewes and the concomitant variation in the endometrial expression mRNA encoding IGF-I and IGFBP-2 are novel findings.

A temporal variation in endometrial expression of mRNA encoding IGF-I in ewes was identified in the present study with an increase at oestrus and on days 6 and 8 of pregnancy compared with day 15 of pregnancy. The timing of increased endometrial expression of mRNA encoding IGF-I in this study coincides with both high plasma oestrogen concentrations at oestrus (Karsch et al., 1980) and the hatching of the blastocyst (Bindon, 1971), while the low endometrial expression of mRNA encoding IGF-I on day 15 coincides with the beginning of adherence of the embryo to the uterine wall in ewes (Bindon, 1971). Previous studies in sheep have also demonstrated that the IGF-I content of uterine luminal fluid on day 16 of pregnancy is lower than that on day 10 of pregnancy (Ko et al., 1991). In the present study, relatively low endometrial expression of mRNA encoding IGF-I in ewes was observed on day 15 of pregnancy and this was used as a reference point of comparison for the mRNA expression of all other genes examined. The mRNA encoding the IGF-I receptor is also expressed during early pregnancy in ewes in the endometrium (Stevenson et al., 1994) and on the embryo (Watson et al., 1994), suggesting pathways for IGF-I action. Taken together these observations suggest a specific role of IGF-I in the uterus during early pregnancy but not during the period when the embryo adheres to the uterine wall.

However, Stevenson et al. (1994) localized mRNA encoding IGF-I in endometrial tissue of ewes and showed relatively high expression at oestrus, with no effect of day of pregnancy. The discrepancy between the present study and that of Stevenson et al. (1994) may reflect discrete differences in the timing of sampling in the two studies. Wathes et al. (1994) demonstrated (a)

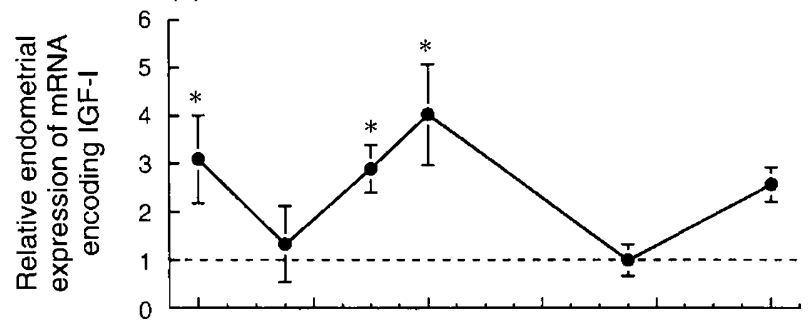

(b)

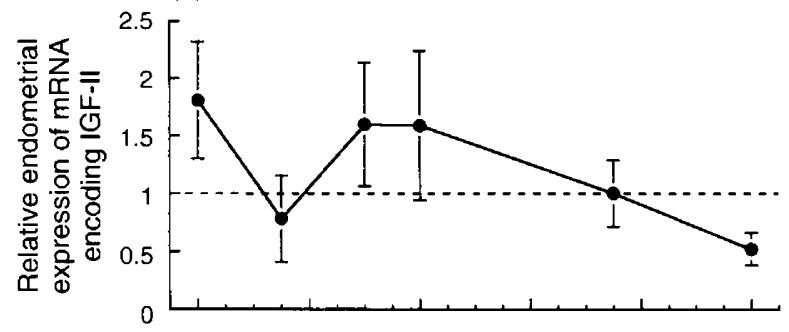

(c)

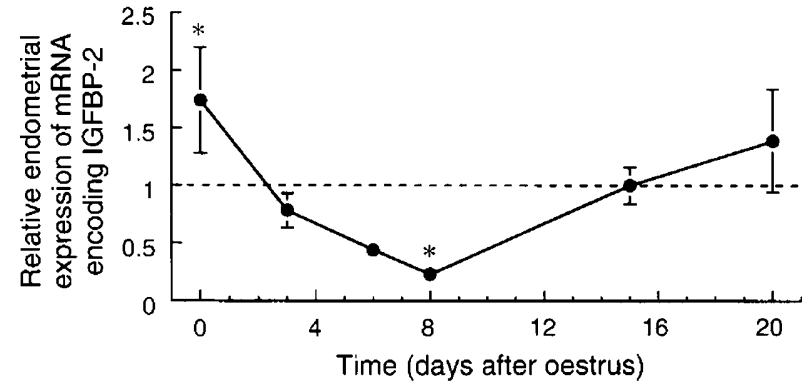

Fig. 4. Endometrial expression of mRNA encoding (a) insulin-like growth factor I (IGF-I), (b) IGF-II and (c) insulin-like growth factor binding protein 2 (IGFBP-2) relative to the mean value recorded on day 15 of pregnancy in ewes. Values (means \pm SEM; $n=5$ at each time point except on day 20 where $n=4$ ) are corrected for loading by comparison with endometrial expression of mRNA encoding glyceraldehyde phosphate dehydrogenase. * Significant differences $(P<0.05)$ relative to day 15 of pregnancy.

a narrow window of induction of endometrial expression of mRNA encoding IGF-I at oestrus coincident with the LH surge that decreased to a basal concentration $10 \mathrm{~h}$ later. The observations in the study of Stevenson et al. (1994) may indicate that the collection of the oestrous samples coincided in that study with the narrow window of expression of mRNA encoding IGF-I. In contrast, the findings of the present study suggest that such alignment of sample collection and the short-lived expression of mRNA encoding IGF-I did not occur in this case. Such a scenario is feasible given the variance in the time of detection of oestrus of $24 \mathrm{~h}$ in both studies.

In addition, differences in the presentation of data showing the expression of mRNA encoding IGF-I may explain the discrepancies between these studies. In the study of Stevenson et al. (1994) the expression of mRNA encoding IGF-I from both nonpregnant and pregnant animals was combined except on days 14-15 when data from nonpregnant ewes only were reported. The data showing the expression of mRNA encoding IGF-I in the present study are presented relative to day 15 of pregnancy when oestrogen concentrations were very low. 
Given the suggested induction of mRNA encoding IGF-I by oestrogen at oestrus, both in the present study and in that of Stevenson et al. (1994), the apparent increase in mRNA encoding IGF-I expression on days 6 and 8 of pregnancy relative to day 15 of pregnancy in the present study may be attributed to the relatively low expression of mRNA encoding IGF-I on day 15 of pregnancy coinciding with low oestrogen concentrations. Alternatively, the discrepancy between these studies may reflect breed differences in the expression of mRNA encoding IGF-l or in factors regulating this gene: Clun-Forest ewes were used in the study of Stevenson et al. (1994) and Merino ewes in the present study.

Previous workers have also detected temporal variations in the endometrial expression of mRNA encoding IGF-I in other species, with increased expression being frequently associated with high plasma oestrogen concentrations, such as at oestrus in cows (Geisert et al., 1991). Similarly, in sows, a peak in endometrial expression of mRNA encoding IGF-I occurs on day 12 of pregnancy, coinciding with elongation of the embryo and the subsequent embryonic secretion of significant concentrations of oestrogen (Simmen et al, 1992). High uterine expression of mRNA encoding IGF-I has also been demonstrated in ovariectomized rats after administration of oestrogen (Murphy and Friesen, 1988). Collectively, these data suggest a role of IGF-I in the mediation of oestrogenic actions in the uterus of ewes. The increased expression of mRNA encoding IGF-I at oestrus observed in the present study supports this hypothesis.

However, in the present study, the increased endometrial expression of mRNA encoding IGF-I on day 6 and day 8 of pregnancy, when oestrogen concentrations are very low, suggests that other factors such as progesterone may also play a role in the induction of uterine expression of mRNA encoding IGF-I in ewes. Furthermore, the relative decrease in the endometrial expression of mRNA encoding IGF-I on day 15 of pregnancy, after maternal recognition of pregnancy and the beginning of adherence of the embryo to the uterine wall, suggests that factors associated with these events may also be related to the expression of mRNA encoding IGF-I. Ko et al. (1991) demonstrated a stimulatory effect of combined IGF-I and IGF-II on interferon- $\tau$ secretion by sheep conceptuses in vitro, but no effect of either peptide alone. This finding suggests that IGF-I and IGF-II have a specific role in the development of the embryo or the maternal environment during the preimplantation period in ewes. This role may be under the regulation of both oestrogen and progesterone, or other factors, and requires further investigation. Upregulation of the endometrial expression of mRNA encoding IGF-I by either oestrogen or progesterone has been demonstrated in the ovariectomized pig (Simmen et al., 1990).

The low endometrial expression of mRNA encoding IGF-II and the lack of an effect of day of pregnancy on its expression shown in the present study confirm similar reports in cows (Geisert et al., 1991) and ewes (Stevenson et al., 1994). Therefore, it is suggested that while mRNA encoding IGF-II is present in the endometrium of ewes, the steroid-induced changes throughout early pregnancy do not affect expression of this gene. In contrast to the mRNA encoding IGF-I, the mRNA encoding IGF-II has been shown to be expressed abundantly in the human fetus (Han et al., 1988), which may indicate a more important paracrine role of IGF-II in postimplantation and fetal life. However, the pattern of endometrial expression of mRNA encoding IGF-II found during early pregnancy, both in sheep in the present study and in other species (Geisert et al., 1991), suggests that IGF-II may also play an autocrine role in the development of the uterus itself and, thereby, an indirect role in the development of the preimplantation embryo.

The endometrial expression of mRNA encoding IGFBP-I in ewes on day 15 of pregnancy demonstrated in this study coincides with the adherence of the embryo to the uterine wall and is in agreement with findings showing pregnancy-specific localization of IGFBP-1 in the luminal epithelium of sheep uterus from day 10 to day 14 of pregnancy (Waites et al., 1990). An association between IGFBP-1 and implantation events has also been reported in other species with reports of expression of mRNA encoding IGFBP- 1 in baboon endometrium during the late luteal phase (Fazleabas et al., 1989), in decidual cells of rat endometrium (Croze et al., 1990) and in implantation sites of cats (Boomsma et al., 1994). Hustin et al. (1994) have also shown that IGFBP-I is present in human endometrium. Although the relative invasion of the trophoblast in these species is more significant than the noninvasive implantation characteristic of ruminants, these studies support the results of the present study in suggesting a role of IGFBP-I in implantation and adherence.

Progesterone induction of immunoreactive IGFBP-1 has also been reported in the endometrium of women (Suhonen et al., 1996), suggesting that progesterone plays a role in the regulation of IGFBP-1 in the uterus. However, this hypothesis contradicts the pregnancy-specific localization of IGFBP-I in the uterus observed by Waites et al. (1990). Further studies of the expression of mRNA encoding IGFBP-1 are required to investigate the regulatory mechanisms controlling IGFBP-1 in the uterus of ewes in regard to possible roles for this protein during early pregnancy.

Although the nature of the role of IGFBP-1 in the uterus around the time of adherence in ewes is unclear, there is evidence of modulation of the action of IGF by IGFBP-1. Inhibition of the biological actions of the IGFs by IGFBP-I has been reported in a variety of in vitro bioassays (Knauer and Smith, 1980; Burch et al., 1990), while purified human IGFBP-1 potentiated replication of several cell types (Elgin et al., 1987). The induction of mRNA encoding IGFBP- 1 on day 15 of pregnancy coinciding with relatively low expression of mRNA encoding IGF-I, as demonstrated in this study, suggests downregulation of the IGF-I gene. This may serve to inhibit the mitogenic actions of IGF-I and IGF-II on the endometrium around the time of adherence of the embryo to the uterine wall by reducing the activity of either IGF through the formation of an IGF-IGFBP complex. Alternatively, maternally derived IGFBP-I may promote IGF action at this time by modulation of IGF transport across the epithelium to the uterine lumen.

The detection of mRNA encoding IGFBP-2 throughout early pregnancy in the present study suggests a potential role of this protein in the regulation of IGF action in the uterus during early pregnancy in ewes. This is supported by the findings of Stevenson et al. (1994) that IGFBP-1 or IGFBP-2, or both, may be produced locally in the deep stroma and glands of the ovine uterus. However, the observations of the present 
study are not in agreement with those of Reynolds et al. (1995) who reported the absence of mRNA encoding IGFBP-2 from uterine tissue from day 13 to day 55 of pregnancy in ewes. The reason for this discrepancy is unclear, but the increased expression of mRNA encoding IGFBP-2 at oestrus, like that of IGF-I, suggests the induction of both genes by oestrogen, as has been proposed to occur in cows (Geisert et al., 1991) and sows (Simmen et al, 1992).

Furthermore, the expression of mRNA encoding IGFBP-2 in the present study tended to be inversely proportional to that of IGF-1, and expression of mRNA encoding IGFBP-2 was less on day 8 of pregnancy relative to expression on day 15 of pregnancy. This difference between the expression of the mRNAs of these two genes suggests a downregulation of IGFBP-2 expression which coincides with relatively high expression of mRNA encoding IGF-I. These changes in the expression of mRNA encoding IGFBP-2 may modulate the action of IGF by regulating the proportion of IGFs held as complexes, particularly on day 8 of pregnancy when the contrast in the expression of mRNAs encoding IGF-I and IGFBP-2 was most apparent. However, given the relative avidity of IGF-II for IGFBP-2, this regulatory mechanism may be more important for the regulation of IGF-II activity than that of IGF-I. Alternatively, the high expression of IGFBP-2 at oestrus and during the period leading up to adherence of the embryo to the uterine wall may regulate the transport of IGF-I or IGF-II, or both, in the uterus or may act as a local store for IGF-II.

In conclusion, variations in endometrial expression of mRNA encoding members of the IGF system may indicate a role of IGF-I and IGF-II in the development of the ovine embryo, and both IGFBP-1 and IGFBP-2 may modulate the action of IGF-I and IGF-II in the uterine environment.

This work was performed, in part, at the Victorian Institute of Animal Science (VIAS), Werribee and the authors acknowledge the assistance of VIAS and staff. The work was undertaken with the assistance of an Australian Meat Research Corporation grant to R. J. Fairclough, and C. H. Cann was the recipient of a La Trobe University Postgraduate Research Award.

\section{References}

Bar RS, Boes M, Clemmons DR, Busby WH, Sandra A, Dake BL and Booth BA (1990) Insulin differentially alters transcapillary movement of intravascular IGFBP-1, IGFBP-2 and endothelial cell IGF binding proteins in rat heart Endocrinology 127 497-499

Baxter RC (1991) Insulin-like growth factor (IGF) binding proteins (BP): the role of serum IGFBPs in regulating IGF availability Acta Paediatrics Scandinavia Supplement 372 107-115

Bindon BM (1971) Systematic study of preimplantation stages of pregnancy in the sheep Australian Journal of Biological Science 24 131-147

Boomsma RA, Mavrogianis PA, Fazleabas AT, Jaffe RC and Verhage HG (1994) Detection of insulin-like growth factor binding protein-1 in cat implantation sites Biology of Reproduction 51 392-399

Brigstock DR, Heap RB and Brown KD (1989) Polypeptide growth factors in uterine tissues and secretions Journal of Reproduction and Fertility 85 747-758

Burch WM, Correa J, Shively JE and Powell DR (1990) The 25 kilodalton insulin-like growth factor (IGF)-binding protein inhibits both basal and IGF-I mediated growth of chick embryo pelvic cartilage in vitro. Journal of Clinical Endocrinology 70173

Chirgwin JM, Przybyla AE, MacDonald RJ and Rutter WJ (1979) Isolation of a biologically active ribonucleic acid from sources enriched in ribonuclease Biochemistry 18 5294-5299
Cohen KL and Nissley SP (1976) The serum half-life of somatomedin activity: evidence for growth hormone dependence Acta Endocrinologica 83 243-258

Croze F, Kennedy TG, Schroedter IC, Friesen HG and Murphy LJ (1990) Expression of insulin-like growth factor-I and insulin-like growth factorbinding protein-1 in the rat uterus during decidualization Endocrinology $\mathbf{7 1}$ 1995-2000

Delhanty PJD and Han VKM (1992) The characterization and expression of ovine insulin-like growth factor binding protein-2 (IGFBP-2) Journal of Molecular Endocrinology 9 31-38

Elgin RG, Busby WH and Clemmons DR (1987) An insulin-like growth factor binding protein enhances the biologic response to IGF-I Proceedings of the National Academy of Science USA 84 3254-3258

Fazleabas AT, Jaffe RC, Verhage HG, Waites G and Bell SC (1989) An insulin-like growth factor-binding protein in the baboon (Papio anubis) endometrium: synthesis, immunocytochemical localization, and hormonal regulation Endocrinology 124 2321-2329

Geisert RD, Lee C-Y, Simmen FA, Zavy MT, Fliss AE, Bazer FW and Simmen RCM (1991) Expression of messenger RNAs encoding insulin-like growth factor-I, -II, and insulin-like growth factor binding protein-2 in bovine endometrium during the estrous cycle and early pregnancy Biology of Reproduction 45 975-983

Ghahary A and Murphy LJ (1989) Regulation of uterine insulin-like growth factor-I receptors by estrogen and variation throughout the estrous cycle Endocrinology 125 597-604

Han VKM, Lund PK, Lee DC and D'Ercole AJ (1988) Expression of somatomedin/insulin-like growth factor messenger ribonucleic acids in the human fetus: identification, characterization, and tissue distribution Journal of Clinical Endocrinology and Metabolism $66422-429$

Harvey MB and Kaye PL (1991) IGF-2 receptors are first expressed at the 2-cell stage of mouse development Development 111 1057-1060

Heyner S, Smith RM and Schultz GA (1989a) Temporally regulated expression of insulin and insulin-like growth factors and their receptors in early mammalian development Bioessays 11 171-176

Heyner S, Rao V, Jarrett L and Smith RM (1989b) Preimplantation mouse embryos internalize maternal insulin via receptor-mediated endocytosis: pattern of uptake and functional correlations Developmental Biology 134 $48-58$

Hustin J, Philippe E, Teisner B and Grudzinskas JG (1994) Immunohistochemical localization of two endometrial proteins in the early days of human pregnancy Placenta 15 701-708

Karsch FJ, Legan SA, Ryan KD and Foster DG (1980) Importance of estradiol and progesterone in regulating $\mathrm{LH}$ secretion and estrous behaviour during the sheep estrous cycle Biology of Reproduction 23 404-413

Knauer DJ and Smith GL (1980) Inhibition of biological activity of multiplication-stimulating activity by binding to its carrier protein Proceedings of the National Academy of Science USA 777252

Ko Y, Lee CY, Ott TL, Davis MA, Simmen RCM, Bazer FW and Simmen FA (1991) Insulin-like growth factors in sheep uterine fluids: concentrations and relationship to ovine trophoblast protein- 1 production during early pregnancy Biology of Reproduction $\mathbf{4 5}$ 135-142

Letcher R, Simmen RCM, Bazer FW and Simmen FA (1989) Insulin-like growth factor-I expression during early conceptus development in the pig Biology of Reproduction 41 1143-1151

Murphy LJ and Friesen HG (1988) Differential effects of estrogen and growth hormone on uterine and hepatic insulin-like growth factor 1 gene expression in the ovariectomized hypophysectomized rat Endocrinology 122 325-332

Murphy LJ, Seneviratne C, Ballejo G, Croze F and Kennedy TG (1990) Identification and characterization of a rat decidual insulin-like growth factor binding protein cDNA Molecular Endocrinology 4329

Phillips ID, Delhanty PJD and Han VKM (1991) cDNA cloning and ontogeny of expression of insulin-like growth factor binding protein-I (IGFBP-I) mRNA in sheep Abstracts of the Second International Symposium on Insulin-like Growth Factors/Somatomedins D47 309

Rappolee DA, Sturm KS, Schultz GA, Pederson RA and Werb Z (1989) The expression of growth factor ligands and receptors in preimplantation mouse embryos. In Early Embryo Development and Paracrine Relationships, UCLA Symposia on Ceilular Biochemistry, New series 117 11-25 Eds S Heyner and L Wiley. AR Liss, New York

Reynolds TS, Perks CM, Stevenson KR and Wathes DC (1995) Expression of insulin-like growth factor-II (IGF-II) $\mathrm{mRNA}$ and IGF-binding protein 2 (IGFBP2) mRNA during early placental development in the ovine uterus Journal of Endocrinology 147 (Supplement 1) P41 
Simmen FA, Simmen RCM, Geisert RD, Martinat-Botte F, Bazer FW and Terqui M (1992) Differential expression, during the estrous cycle and pre- and postimplantation conceptus development, of messenger ribonucleic acids encoding components of the pig uterine insulin-like growth factor system Endocrinology 130 1547-1556

Simmen RCM, Simmen FA, Hofig A, Farmer SJ and Bazer FW (1990) Hormonal regulation of insulin-like growth growth factor gene expression in pig uterus Endocrinology 127 2166-2174

Stevenson KR, Gilmour RS and Wathes C (1994) Localization of insulin-like growth factor-I (IGF-I) and -Il messenger ribonucleic acid and type I IGF receptors in the ovine uterus during the estrous cycle and early pregnancy Endocrinology 134 1655-1664

Suhonen S, Haukkamaa M, Hoistrom T, Lahteenmaki P and Rutanen EM (1996) Endometrial response to hormone replacement therapy as assessed by expression of insulin-like growth factor-binding protein- 1 in the endometrium Fertility and Sterility 65 776-782
Sutton R, Ward WG, Raphael KA and Cam GR (1995) Growth factor expression in skin during wool follicle development Comparative Biochemistry and Physiology 110B 697-705

Waites GT, Whyte A and Bell SC (1990) Localization of antigen defined by a monoclonal antibody to human $32-\mathrm{kDa}$ insulin-like growth factor-binding protein in the sheep uterus at preimplantation stages of pregnancy Placenta $11233-240$

Wathes DC, Perks CM and Stevenson KR (1994) Insulin-like growth factor I (IGF-l) synthesis in the ovine reproductive tract: possible interactions between the uterus and ovary Proceedings of the 26th Annual Conference of the Australian Society for Reproductive Biology 2654

Watson AJ, Watson PH, Arcellana-Panilio M, Warnes D, Walker SK, Schultz GA, Armstrong DT and Seamark RF (1994) Growth factor phenotype map for ovine preimplantation development Biology of Reproduction 50 725-733

Werb Z (1990) Expression of EGF and TGF- $a$ genes in early mammalian development Molecular Reproduction and Development 27 10-15 